\title{
The Impact of Earnings Management on Dividend Policy: Evidence From Kuwait
}

\author{
Sinan S. Abbadi ${ }^{1}$, Murad Y. Abuaddous ${ }^{1}$, Hanady T Bataineh ${ }^{1}$ \& Abdulla E Muttairi ${ }^{1}$ \\ ${ }^{1}$ Al-Balqa' Applied University, Jordan \\ Correspondence: Sinan S. Abbadi, Al-Balqa' Applied University, Jordan.
}

Received: July 7, 2020

Accepted: August 12, 2020

Online Published: October 5, 2020

doi:10.5430/ijfr.v11n5p518

URL: https://doi.org/10.5430/ijfr.v11n5p518

\begin{abstract}
This study has two main objectives. The first is to examine the impact of Earnings Management (EM) on dividend policy for the Kuwait's industrial and service sectors. The second is to sieve out the possible explanations for the conflicting results regarding this topic. Using Modified Jones Model, a sample of 46 companies listed on the Kuwait Stock Exchange with a total of (184) firm-year observations form the period 2011-2016 reveals an absence of a significant relation between EM and dividend policy. In addition, this paper posits a possible relationship between EM, dividend policy and market maturity.
\end{abstract}

Keywords: earnings management, dividend policy, discretionary accruals, Kuwait Stock Exchange, modified Jones Model

\section{Introduction}

Corporate managers generally encounter some crucial decisions regarding their company's finances. In this regard, dividend policy decisions are sine qua non financial decisions as they are perceived as a symbol of good financial standing. To this date, a broad strand of literature investigates the factors which impact a company's dividend policy such as credit limit, real and financial investment chances and choices, size of the organization and company's laws or regulations. A recent paradigm shift puts forward some evidences that dividend policy can also be utilized for creative accounting decisions (Moghri \& Galogah, 2013).

Despite the commendable strides of prior research so far, the debate about EM as a predictor for dividend policy decisions is still unsettled. This debate was fragmented by the view that dividends can be a predictor of earnings and earnings can also be a predictor of dividends. Therefore, it is not surprising that the reigning assumption in prior literature assumes that managers are motivated to manipulate earnings and utilize creative accounting through dividends (Shah, Yuan \& Zafar, 2010).

According to Healy and Wahlen (1999): "earnings management occurs when managers use judgment in financial reporting and structuring transactions to alter financial reports to either mislead some stakeholders about the underlying economic performance of the company or to influence the contractual outcomes that depend on reported accounting numbers". Hence, this research delves in the Kuwaiti stock market to investigate this phenomenon as we assume that Kuwaiti managers are equally motivated to practice EM. In essence, this study examined the effect of EM on dividend policy for the Kuwaiti industrial and service companies listed on the Kuwait stock exchange.

Recently, some prior studies have accentuated some scattered findings regarding the relationships between EM and dividend policy (i.e. Amar, Salah \& Jarboui, 2018; Vieira, 2017; Tangestani, Asgari \& Jahed, 2016). From a theoretical perspective, these studies have captured positive, negative and neutral relationship between EM and dividend policy with a conspicuous lack of befitted explanations. Thus, to the best of the authors' knowledge, this study has two main objectives. Firstly, is conducting a quantitative measurement to explore the impact of companies' dividend policy in EM decision in Kuwaiti industrial sector. Secondly, is drawing possible explanations for the contradicting results found in prior literature.

To fulfill these objectives, this study adopted 43 Kuwaiti industrial and service companies listed on the Kuwait stock exchange between 2013-2016. The sample was tested using Dechewo, Sloan, \& Sweeney (1995) modified Jones model to investigate whether managers are utilizing dividend policy for EM practices. 
The rest of the paper unfolds as follows; Section 2 provides the theoretical background and develops hypothesis of the study. Section 3 presents the methodology of the study and describes the data. Section 4 discusses the results. Section 5 summarizes and concludes this study and provides recommendations and suggestions for future research.

\section{Theoretical Background}

\subsection{Earnings Management}

Despite the absence of a unique definition for EM, the triggering motives for EM can be rooted back to the flexibility provided by the accounting standards (Abuaddous, Hanefah \& Laili, 2014). Contextually, this flexibility can enable managers to manipulate reported results (Riahi-Belkaoui, 2004; Nigrini, 2005). As a matter of fact, managers can practice EM by presenting a more favorable financial status of the company's performance through discretionary accruals (Aman, Pourjalali \& Teruya, 2006), contractual obligations and debt covenants to achieve the best means of any contractual deals (Healy \& Wehlen 1999). Indeed, all these practices by managers can be explained by the agency theory.

Unlike in fraudulent accounting where management is deliberately infringing on the financial reporting standards, EM uses the allowed accounting choices by accounting standards. Hence, EM is an aggressive or conservative adoption of accounting standards to distort financial outcomes (Dechow and Skinner, 2000).Prior studies have shown two schools of thoughts in regards to EM (i.e. accrual management and the manipulation of real economic activities).

On the one hand, management were found to utilize the credit losses, warranty costs, inventory values and timing and amount of unusual items for EM (Cohen \& Zarowin, 2010). On the other hand, EM can be utilized through the use of real variables. In fact, Graham et al. (2005) found that managers are in favor of using real variables to manage earnings. Nonetheless, Schipper (1989) raises an intriguing question about the cost of determining managers' EM tactics. She argued that even more visible EM techniques such as changing accounting policies and timing of capitalization are difficult to sieve out.

\subsection{Dividend Policy}

In essence, dividend policy can be described as a guideline which management follows to declare dividend. The absence of predetermined rules for setting dividend policies bolsters management's role in deciding the proportion of declared dividends and the retained earnings. With this in mind, retained earnings are considered an important source of internal finance for the long-term growth of a company while dividends reduce the available cash funds of a company. In fact, this reciprocal relation between dividends and retained earnings can impinge on management efficiency in balancing the various stakeholders' and company's needs.

Moyer (2012) argued that dividend policy determines the ultimate distribution of the firm's earnings between retention and cash dividend payments to shareholders. While Ronald, John, Kalay, Loewenstein \& Sarig (2000) described dividend policy as the practice of making dividend payout decisions, size and pattern of cash distributions over a period of time to shareholders. Therefore, it is expected that management decisions about dividend policy are taken in congruence with firm's objectives in order to choose the best policy and to maximize the value of the firm (Van Horne, 1979). The importance of setting such policies may go beyond the amount of the money involved, but rather to achieve some other objectives regarding the company's financial and investment future decisions. For example, Bataineh, Abuaddous \& Alabood (2018) found that family firms' decisions in Jordan are not only dependent on maximizing the owner wealth but also involve in maintaining a certain image and heritage of the family firms. Hence, company's dividend policy can be affected by various factors such as market imperfections, behavioral considerations, firm characteristics or managerial preferences (Baker, Parasuraman, Grewal \& Voss, 2002). As a result, management should carefully consider answering questions about the amount, the method, retained profit and all other related outcomes of paying dividends.

The aforementioned description of the management role and incentives in determining dividend policy necessitates the introduction of agency cost to this mixture. Managers are susceptible to agency cost theory (Type I) which requires monitoring the furnished dividends payment in order to reduce the agency cost. This can be accomplished by reducing the discretionary funds available to managers (Jensen and Meckling, 1976). In fact, this argument was early supported in literature as Jensen \& Meckling (1976) introduced agency theory in which companies pay dividends to reduce agency and transaction costs related to recently issued equity. Their study concluded that higher dividend payments reduce the agency conflicts between managers and shareholders.

A large body of literature highlighted the factors which can influence dividend policy. Evidences suggest that company's age, size, profitability, cash balance, ROE and financial leverage have an influence in the company's dividend policy. In this sense, company's age was found to have a direct relation with its dividend policy. A startups 
or under growth companies were not likely to pay dividends until reaching maturity phase (Higgins, 1972). This proposition was supported by some studies which argued that large firms distribute higher amounts of their net profits as cash dividends than small firms (Fama \& Frensh, 2000). However, other studies argued that in most cases, SME's managers feel more reluctant to distribute dividends than managers in large companies (Atieh \& Hussain, 2012).

Company's performance, ROE, cash flow and financial leverage were also found to impact dividend policy. ROE which reflects the shareholders' wealth has a direct positive impact on the company's dividend policy (Priya \& Mohanasundari, 2016). Further, dividend payments are also influenced by company's cash flows. Brealey, Myers, Allen \& Mohanty (2012) argued that managers will not raise dividends unless they are optimistic about adequate cash flow. Finally, financial leverage can impact the dividend policy when highly leveraged firms maintained their internal cash flow in order to fulfill their duties rather than distributing available cash to shareholders (Agrawal and Jayaraman, 1994).

\subsection{Earnings Management and Dividend Policy}

The burgeoning interest in the impact of EM on company's dividend policy had led to multiple studies which investigate this relation. From a theoretical perspective, dividends declaration does not seem to be a reasonable option when managers are engaged in EM practice as they intend to keep their numbers attractive. In other words, dividend declaration was believed to be the answer to the agency theory conflict between managers and stockholder. Hence, it is expected that when companies declare dividend, the various parties involved with conflicting priorities will receive this news ardently. This conclusion leads one to expect a negative or no effect between EM and dividend policy. However, recent studies suggest that managers tend to utilize EM to maintain a consistent level of dividend payout which results in a positive relationship between EM and dividend policy.

These open scenarios suggest that dividend polices and EM are both subject to the circumstantial situation of the company which can determine the expected trend of such relation. For example, a positive relation between EM and dividend policy was detected when managers are pinned with high dividend policy which require them to maintain consistency (Im, Kim, \& Choi, 2015). A similar conclusion was drawn by Mellado-Cida \& Ngob (2014) who conducted a 25-year panel study and found a positive relation between EM and dividend policy in NASDQ. In addition, Amar et al. (2018) found a positive impact of EM on dividend policies in French firms. While Chansarn \& Chansarn (2016) found that earnings management had a positive influence on dividend yields of small and medium sized enterprises in Thailand.

Another stream of the literature documents a negative relationship between dividend policy and EM. These findings contradict the previous argument of EM and dividend policy interaction, by assuming that dividend declaration is a useful managerial tool to mitigate the agency problem. Thus, dividend declaration can ensure that managers are carrying the business at a rather more sedate pace. Savov (2006) examined the relationship between investment, EM and dividend payment, the results revealed a negative relationship between EM and dividend payout policy. In a similar manner, Ajide \& Aderemi (2014) found a negative relationship between EM and dividend policy using a non-financial institutions sample from the Nigerian Stock Exchange. Srikanth and Prasad (2015) studied the effect of EM on dividend policy in India. The study adopted both discretionary and non-discretionary accruals for EM while dividend pay-out was utilized for dividend policy measurement. The study showed that discretionary accruals variable is negatively influencing the dividend payout. Vieira (2017) found negative association between earnings management and payout policy for the G5 countries. She explained that payout policy can be used as a form of mitigation to agency problems. Ajide \& Aderemi (2014) suggested that EM has negative relationship with dividend policy in Nigerian firms and it is not significant in the determination of dividend payout of every firm.

The last stream of studies did not capture such relationship between EM and dividend polices. Shah et al. (2010) conducted a comparative study between Pakistani and Chinese that investigates the relationship between EM and dividend policy. Their results confirmed that in both countries EM has no impact on dividend policy. Saleem \& Alifiah (2017) examined the effect of earnings management on dividend policy for (104) Pakistani listed companies' between 2008 and 2015. The study adopted the dividend payout ratio and Dechow et al. (1995) and showed no significant relationship. In addition, Tangestani et al. (2016) posit that companies listed on the Tehran Stock Exchange did not show any significant relationship between dividend and earnings management. In line with our expectations, these studies showed that involvement of managers in earnings management is not motivated by dividend policy.

Despite the plethora of studies about divided policy and EM, only few studies attempt to explore the possible explanation of these conflicting results. Baker et al., (2002) put forward four possible explanations for dividend 
policy setting (i.e. market imperfections, behavioral considerations, firm characteristics or managerial preference). On the other hand, prior research papers on EM and dividend policy were only able to explain their results without explaining the contradicting results of other studies.

To inform this debate, the authors find it interesting that positive results were only found in countries such as USA, UK, France and Korea. While negative and no results were found in the G5 countries, Nigeria, Pakistan and Iran. This trend may indicate a possible relationship between market maturity, dividend policy and EM. To put it differently, companies in a more mature market environment are more motivated to utilize EM for dividend distribution in order to keep a good image. In the other hand, companies functioning under emerging economies are more interested in resolving the agency problem. This can explain the negative relation between EM and dividend policy or the absence of such relation.

Following aforementioned logic, Kuwait is no exception to countries under emerging economies. Thus, we posit the following hypothesis:

\section{Ho: Earnings management has no significant impact on dividend policy in nonfinancial companies listed on the Kuwait Stock Exchange.}

\section{Research Design}

The purpose of this study is to examine the impact of EM on dividend policy for the non-financial companies listed in the Kuwait Stock Exchange. To achieve this objective, data was collected from 46 financial statements of the industrial and service companies listed on the Kuwait Stock Exchange between 2011 and 2016.

\section{Variables Measurement}

As discussed in the previous sections, this study emphasizes on two variables (i.e. EM and dividend policy) and 5 controlled variables (i.e. cash flow, return on equity, total assets, financial leverage, and company age). This study adopted multiple regression analysis to test the relationship between dividend policy and EM. Following modified Jones model, this study examines the effect of EM on dividend policy using the empirical form of the model set below:

$$
\mathrm{Di}=\beta 0+\beta 1(\mathrm{EM})+\beta 2(\mathrm{LEV})+\beta 3(\mathrm{CF})+\beta 4(\mathrm{ROE})+\beta 5(\text { assets })+\beta 6(\text { age })
$$

Where;

Di $=$ Dividends Policy

EM= Earnings Management

LEV= Financial Leverage

$\mathrm{CF}=$ Operating Cash flows

$\mathrm{ROE}=$ Return on Equity

ASSETS $=$ Total Assets

AGE $=$ Age of the firm

Literature has used discretionary accruals as a proxy for earnings management (Healy, 1985; Jones et al., 1991; and Dechow et al. 1995). The modified Jones model was proven to provide the most befitting model for estimating discretionary accruals (Dechow et al., 1995; Guay, Kothari \& Watts, 1996; Koren \& Valentincic, 2013). Hence, this study adopts Dechow et al. (1995) to calculate discretionary accruals and differences between total accruals and non-discretionary accruals. Consequently, discretionary accruals would be measured as follows:

Step 1: Total accruals as previously mentioned is the difference between earnings and cash flows from operating activities

$$
\text { TACCit }=\text { NIit }- \text { OCFit }
$$

Step 2: equation below is estimated for each firm and fiscal year combination

$$
\text { TACCit/TAit-1 = } \alpha 1(1 / \text { TAit-1) }+\alpha 2[(\Delta \text { REVit }) / \text { TAit-1 }]+\alpha 3(\text { PPEit/TAit- } 1)+\varepsilon i t
$$

Step 3: Non-discretionary accruals are measured for each year and fiscal year combination using the equation as follows:

$$
\text { NDACit }=\hat{a} 1(1 / \text { TAit-1 })+\hat{a} 2[(\Delta \text { REVit- } \Delta \text { RECit }) / \text { TAit-1 }]+\hat{a} 3 \text { (PPEit/TAit-1) }
$$


Step 4: The Difference between total accruals and the non-discretionary components of accruals is considered as discretionary accruals (DACC) as stated in equation as follows:

$$
\text { DACCit }=\text { TACCit }- \text { NDACit }
$$

Where:

TACCit $=$ total accruals for company $\mathrm{i}$ in year $\mathrm{t}$

NIit $=$ net income before extraordinary items for company $\mathrm{i}$ in year $\mathrm{t}$

OCFit $=$ operating cash flows for company $\mathrm{i}$ in year $\mathrm{t}$.

TAit-1 $=$ Previous year's total assets

$\triangle \mathrm{REV}$ it $=$ change in operating revenues for company $\mathrm{i}$ in year $\mathrm{t}$

PPEit $=$ gross property, plant and equipment for company $\mathrm{i}$ in year $\mathrm{t}$.

NDACit= non-discretionary accruals for company $i$ in year $t$

$\triangle \mathrm{RECit}=$ change in net receivables for company $\mathrm{i}$ in year $\mathrm{t}$

DACCit $=$ discretionary accruals for company $\mathrm{i}$ in year $\mathrm{t}$

$\alpha 1-\alpha 3=$ regression parameters.

$\varepsilon$ it $=$ error term.

Payout ratio as an independent variable is the percentage of earnings paid out as dividends to stockholders. The payout ratio can also be stated as dividends paid out as a proportion of cash flow. The payout ratio is a key financial metric used to determine the sustainability of a company's dividend payments. The amount that is not paid out in dividends to stockholders is held by the company for growth. A lower payout ratio is generally favorable to a higher payout ratio, with a ratio greater than $100 \%$ signifying the company is paying out more in dividends than its net income.

The Payout Ratio is calculated as follows:

$$
\text { Payout Ratio }=\frac{\text { Dividends per Share }(D P S)}{\text { Earnings per Share }(E P S)}
$$

Table 1 summarizes the study's variables including controlled variables.

Table 1. Variable measurement

\begin{tabular}{ccc}
\hline Variable & Abbreviation & Description \\
\hline Dependent Variable & Di & $\begin{array}{c}\text { Dividend payout ratio calculated as ratio of } \\
\text { DPS to EPS }\end{array}$ \\
\hline Dividend Policy & & $\begin{array}{c}\text { Calculated by using the } \\
\text { Modified Jones Model (1995) }\end{array}$ \\
\hline Independent Variable & EM & \\
\hline Earnings Management & & Ratio of net profit of company to total equity \\
\hline Control Variables & ROE & Calculated using total assets \\
\hline Return on Equity & ASSETS & Ratio of total debt to total assets \\
\hline Total assets & LEV & Cash flows from operating profits \\
\hline Financial Leverage & CF & Age of the firm \\
\hline Cash Flow & Age &
\end{tabular}




\section{Results and Discussion}

\subsection{Descriptive Analysis}

Table 2 shows the descriptive statistics of the study's variables covering 184 firm- year observations from the period between 2013 and 2016. Dividend payout ratio ranges from (0) to (1.31) with a Mean of (0.3881). This indicates that the dividend policies of the Kuwaiti companies are not producing convergent results. On the other hand, the discretionary accruals rang from $(-11,490,274)$ to $(19,596,057)$ with a Mean of $(-761,171)$ indicating that the Kuwaiti companies are utilizing their discretionary accruals to produce their numbers.

The total assets of these companies vary from $(1,692,500)$ to $(1,439,962,500)$ with a Mean of $(125,503,858)$. The financial leverage showed the proportion of company assets that are financed through debt rang from (0) to (0.58) with an average of (0.1739). ROE ranges from (-19\%) to (25\%) and companies' ages range between 10 to 62 years.

Table 2. Descriptive statistics

\begin{tabular}{cccccc}
\hline & $\mathbf{N}$ & Minimum & Maximum & Mean & Std. Deviation \\
\hline Di & 184 & 0.00 & 1.31 & 0.3881 & 0.30396 \\
\hline EM & 184 & -11490274 & 19596057 & -761171 & 4978770 \\
\hline ROE & 184 & -0.19 & 0.25 & 0.0509 & 0.09569 \\
\hline ASSETS & 184 & 1692500 & 1439962500 & 125503858 & 232962628 \\
\hline Lev & 184 & 0.00 & 0.58 & 0.1739 & 0.16262 \\
\hline CF & 184 & -4604250 & 80007250 & 6681815.22 & 14714047.339 \\
\hline Age & 184 & 10 & 62 & 27.91 & 13.132
\end{tabular}

\subsection{Correlation Matrix}

Table 3 displays the correlation matrix. The correlation matrix shows that the only high correlation was found between dividend policy and ROE. This high correlation is expected due to the impact of dividend payments on shareholders' equity which in turn will directly influence the ROE. Other correlation matrix results indicate a low correlation among the rest of the variables which negates the presence of a multicollinearity among the independent variables. According to Field (2013) a multicollinearity problem exists when the correlation coefficient is more than $(0.8)$.

Table 3. Correlation matrix

\begin{tabular}{|c|c|c|c|c|c|c|c|c|}
\hline & & Di & EM & ROE & LEV & Age & CF & ASSETS \\
\hline \multirow{7}{*}{$\begin{array}{l}\text { Pearson } \\
\text { Correlation }\end{array}$} & Di & 1.000 & & & & & & \\
\hline & EM & .124 & 1.000 & & & & & \\
\hline & ROE & .422 & .209 & 1.000 & & & & \\
\hline & Lev & -.281 & -.171 & -.015 & 1.000 & & & \\
\hline & Age & -.065 & -.025 & -.030 & .003 & 1.000 & & \\
\hline & $\mathbf{C F}$ & .086 & -.370 & .047 & .154 & .025 & 1.000 & \\
\hline & ASSETS & .059 & -.259 & .043 & .495 & .108 & .572 & 1.000 \\
\hline
\end{tabular}




\subsection{Regression Analysis}

Table 4. Regression analysis

\begin{tabular}{ccccc}
\hline Model & Coefficients & Std. Error & T & Sig. \\
\hline (Constant) & -.836 & 1.032 & -.810 & 0.422953 \\
\hline EM & $1.511 \mathrm{E}-09$ & .000 & .253 & 0.801365 \\
\hline ASSETS & .193 & .142 & 1.359 & 0.182007 \\
\hline ROE & .956 & .335 & 2.857 & $\mathbf{0 . 0 0 6 8 2 2}$ \\
\hline LEV & -1.063 & .424 & -2.508 & $\mathbf{0 . 0 1 6 4 1 3}$ \\
\hline Age & -.003 & .004 & -.582 & 0.563622 \\
\hline CF & $-1.042 \mathrm{E}-10$ & .000 & -.020 & 0.984053 \\
\hline \multicolumn{5}{c}{ R-squared } \\
\hline \multicolumn{5}{c}{ Adjusted } \\
R-squared & .550 .195148 \\
\hline & F-statistic & \\
\hline \multicolumn{5}{c}{ Prob(F-statistic) } \\
\hline
\end{tabular}

Table 4 shows the estimated result of the study equation. The P-value of F-statistic is equal to (0.022) which indicates that the model is statistically significant. In addition, R square shows that our model explained (55\%) of total variations of the dependent variable which is consisted with prior literatures (e.g. Ajide \& Aderemi, 2014; Im et al., 2015; Amar et al., 2018). Alternatively stated, (55\%) of the changes in the study's dependent variable (dividend policy) are explained by both independent and control variables.

In line with our expectations, this paper hypothesizes that EM has no significant impact on dividend policy in industrial and service companies listed on the Kuwait Stock Exchange. Our findings suggest that discretionary accruals have a coefficient of (-1.511E-09) with t-statistic of (-0.810) and a p-value of (0.422953). In that respect, the results confirm the lack of a significant relationship between EM and dividend policy at a significance level of (5\%). Hence, the study supports the established null hypothesis which confirms the absence of a significant relationship between EM and dividend policy.

Numerous studies have shown three possible outcomes (i.e. positive, negative and neutral) for the relation between dividends policy and EM. Consistent with Shah et al. (2010), Tangestani et al. (2016) and Saleem \& Alifiah (2017), our results reiterated the absence of a significant relationship between dividend policy and EM in the Kuwaiti market.

The dearth of a credible explanation for the outcome variation in literature may hinder providing a neat explanation for our results. However, as discussed in the previous section, the literature indicates a possible relationship between market maturity, dividend policy and EM. Our results bolstered this conclusion as the Kuwaiti market is considered an emerging economy where agency and market trust problems are more floating on the surface. Moreover, the Kuwaiti market is still lacking of an active market that allows investors to pressurize managers to manipulate earnings (positively or negatively) through their dividend policies.

Thus, unlike managers in developed markets who are more motivated to utilize EM in pursuing more consistent dividend payments (Im et al., 2015; Mellado-Cida and Ngob, 2014; Amar et al., 2018), managers of Kuwaiti companies are expected to react similar to those of under developing countries who show negative relation between dividend policy and EM to mitigate an agency problem (Ajide \& Aderemi, 2014; Srikanth and Prasad, 2015; Vieira, 2017), or with no relation between dividend policy and EM in the absence of such conflict.

Turning to the results, this study finds a positive and significant relationship between ROE and dividend policy. This expected finding is consistent with the Higgin (1972) sustainable growth model which states that the absence of financial constrains for companies leads to payment of surplus funds. In addition, the study also finds a negative and significant relationship between financial leverage (LEV) and dividend policy. Finally, the results show a negative and insignificant relationship between companies' ages and cash flow variables with dividend policy, whereas, a positive but insignificant relationship was found between total Assets variable and dividend policy. 


\section{Conclusion}

This study examined the effect of EM on dividend policy for the Kuwaiti industrial and service companies listed on the Kuwait Stock Exchange. Our results indicate the absence of a significant relation between EM and dividend policy. Hence, this study expects that Kuwait as an emerging economy is still lacking of a dynamic and mature stock market which allows investors to pressurize the companies to react creatively (positively or negatively) through their dividend policies.

The implications of our findings are manifold; policy makers should pay further attention to the role of dividend distribution in reducing agency problem. In addition, EM is still a terra incognita to almost all investors, policy makers should carefully monitor the dividend policy within their market to achieve the best outcomes to the various shareholders.

We also identify some potential areas for future research. Firstly, the relation between the market maturity, EM and dividend policy is still missing in the literature. Secondly, across countries comparison will also allow for better understanding of the possible explanation for the contradicting results appearing in EM and dividend policy relationship. Finally, family business, dividend policy and EM can also be subject to other explanatory theories such as the socio-emotional wealth theory.

\section{References}

Abuaddous, M., Hanefah, M. M., \& Laili, N. H. (2014). Accounting standards, goodwill impairment and earnings management in Malaysia. International Journal of Economics and Finance, 6(12), 201.

Agrawal, A., \& Jayaraman, N. (1994). The dividend policies of all-equity firms: A direct test of the free cash flow theory. Managerial and Decision Economics, 15(2), 139-148.

Ajide, F. M., \& Aderemi, A. A. (2014). The Effects of Earnings Management on Dividend policy in Nigeria: An Empirical Note. The SIJ Transactions on Industrial, Financial \& Business Management (IFBM), 2(3), 145-152.

Aman, A., Pourjalali, H., \& Teruya, J. (2006). Earnings management in Malaysia: A study on effects of accounting choices. Malaysian Accounting Review, 5(1), 185-209.

Amar, A. B., Salah, O. B., \& Jarboui, A. (2018). Do discretionary accruals affect firms' corporate dividend policy? Evidence from France. Journal of Financial Reporting and Accounting, 16(2), 333-347.

Atieh, A., \& Hussain, S. (2012). Do UK firms manage earnings to meet dividend thresholds?. Accounting and Business Research, 42(1), 77-94.

Baker, J., Parasuraman, A., Grewal, D., \& Voss, G. B. (2002). The influence of multiple store environment cues on perceived merchandise value and patronage intentions. Journal of Marketing, 66(2), 120-141.

Bataineh, H., Abuaddous, M., \& Alabood, E. (2018). The Effect of Family Ownership and Board Characteristics on Earnings Management: Evidence from Jordan. Academy of Accounting and Financial Studies Journal.

Brealey, R. A., Myers, S. C., Allen, F., \& Mohanty, P. (2012). Principles of corporate finance. Tata McGraw-Hill Education.

Chansarn, S., \& Chansarn, T. (2016). Earnings Management and Dividend Policy of Small and Medium Enterprises in Thailand. International Journal of Business \& Society, 17(2).

Cohen, D. A., \& Zarowin, P. (2010). Accrual-based and real earnings management activities around seasoned equity offerings. Journal of Accounting and Economics, 50(1), 2-19.

Dechow, P. M., \& Skinner, D. J. (2000). Earnings management: Reconciling the views of accounting academics, practitioners, and regulators. Accounting Horizons, 14(2), 235-250.

Dechow, P. M., Sloan, R. G., \& Sweeney, A. P. (1995). Detecting earnings management. Accounting Review, 193-225.

Fama, E. F., \& French, K. R. (2001). Disappearing dividends: changing firm characteristics or lower propensity to pay?. Journal of Financial Economics, 60(1), 3-43.

Field, A. (2017). Discovering statistics using IBM SPSS statistics: North American edition. Sage.

Graham, J. R., Harvey, C. R., \& Rajgopal, S. (2005). The economic implications of corporate financial reporting. Journal of Accounting and Economics, 40(1-3), 3-73.

Guay, W. R., Kothari, S. P., \& Watts, R. L. (1996). A market-based evaluation of discretionary accrual models. Journal of Accounting Research, 34, 83-105. 
Healy, P. M. (1985). The effect of bonus schemes on accounting decisions. Journal of Accounting and Economics, 7(1-3), 85-107.

Healy, P. M., \& Wahlen, J. M. (1999). A review of the earnings management literature and its implications for standard setting. Accounting Horizons, 13(4), 365-383.

Higgins, R. C. (1972). The corporate dividend-saving decision. Journal of Financial and Quantitative Analysis, 7(2), 1527-1541.

Im, C. C., Kim, J. H., \& Choi, M. K. (2015). Dividend policy and earnings management: Based on discretionary accruals and real earnings management. International Journal of u-and e-Service, Science and Technology, 9(2), 137-150.

Jensen, M. C., \& Meckling, W. H. (1976). Theory of the firm: Managerial behavior, agency costs and ownership structure. Journal of Financial Economics, 3(4), 305-360.

Koren, J., \& Valentincic, A. (2013). SHAREHOLDERS'PAY-OUT-RELATED THRESHOLDS AND EARNINGS MANAGEMENT. Economic and Business Review for Central and South-Eastern Europe, 15(2), 151.

Mellado-Cida, C., \& Ngob, T. (2014). Do Dividend Changes Signal Earning Quality? Financial Management Association International. Retrieved from https://www.researchgate.net/profile/Cristhian_Mellado/publication/292129119_Do_Dividend_Changes_Signal _Earning_Quality/links/56a9072008ae7f592f0d5a3e.pdf

Moghri, A. E., \& Galogah, S. S. (2013). Effect of earnings management on dividend policy: evidence from Tehran Stock Exchange. World of Sciences Journal, 1(14), 58-65.

Moyer, R. C., McGuigan, J. R., Rao, R. P., \& Kretlow, W. J. (2012). Contemporary financial management. Nelson Education.

Nigrini, M. J. (2005). An assessment of the change in the incidence of earnings management around the Enron-Andersen episode. Review of Accounting and Finance, 4(1), 92-110.

Priya, V., \& Mohanasundari, M. (2016). Dividend Policy and Its Impact on Firm Value: A Review of Theories and Empirical Evidence. Journal of Management Sciences and Technology, 3(3), 59-69.

Riahi-Belkaoui, A. (2004). Is earnings management affected by human development and economic freedom?. Review of Accounting and Finance, 3(1), 115-127.

Ronald, L., John, K., Kalay, A., Loewenstein, U., \& Sarig, O. (2000). Dividend policy: its impact on firm value. Financil Management Association.

Saleem, F., \& Alifiah, M. N. (2017). The effect of earnings management on dividend policy in Pakistan. Sains Humanika, 9(1-3).

Savov, S. (2006). Changes, signaling, and stock price performance. SSRN 933082.

Schipper, K. (1989). Earnings management. Accounting Horizons, 3(4), 91.

Shah, S. Z. A., Yuan, H., \& Zafar, N. (2010). Earnings management and dividend policy: An empirical comparison between Pakistani listed companies and Chinese listed companies. International Research Journal of Finance and Economics, 35(1), 51-60.

Srikanth, P., \& Prasad, M. D. (2015). Impact of Earnings Management on Dividend Policy: Empirical Evidence from India. Nitte Management Review, 9(1), 14-22.

Tangestani, E., Asgari, V., \& Jahed, I. (2016). The investigation of limiting factors of earnings management for companies' listed Tehran stock exchange. Journal of Fundamental and Applied Sciences, 8(2), 1559-1571.

Van Horne, J. C. (1979). Behavior of default-risk premiums for corporate bonds and commercial paper. Journal of Business Research, 7(4), 301-313.

Vieira, A. I. A. R. S. (2017). Payout policy and earnings management: Dividends versus stock repurchases.

\section{Copyrights}

Copyright for this article is retained by the author(s), with first publication rights granted to the journal.

This is an open-access article distributed under the terms and conditions of the Creative Commons Attribution license (http://creativecommons.org/licenses/by/4.0/). 